\title{
Osteotomía sagital de rama mandibular en cirugía ortognática
}

\section{Sagital split ramus osteotomy of the mandible in orthognathic surgery}

\author{
L.A. Quevedo Rojas
}

Resumen: La Osteotomía Sagital Bilateral de Rama Mandibular (OSBRM) representa la técnica más frecuentemente utilizada en Cirugía Ortognática. Desde su aparición ha sido modificada tanto en diseño, extensión e instrumentación. Se hace un recuento de algunas modificaciones y en esa perspectiva, se explica la técnica que el autor utiliza. Se revisan las ventajas, desventajas, y las posibles complicaciones intra y post operatorias con relación a la Técnica.

Palabras clave: Osteotomía sagital; Cirugía ortognática.

\section{Introducción}

Desde que Hugo Obwegeser describe la Osteotomía Sagital Bilateral de Rama Mandibular (OSBRM) en 1955,1 ha habido muchas modificaciones para este procedimiento quirúrgico que es sin lugar a dudas la técnica quirúrgica más utilizada en Cirugía Ortognática. Los más importantes aportes y modificaciones han sido los de Gregorio Dal Pont, que en 1961, ${ }^{2}$ quien sugiere hacer llegar la osteotomía hacia anterior llevándola por el cuerpo mandibular hasta la altura del segundo y primer molar, donde descendía verticalmente hasta el borde basilar. De esta manera aumentaba la superficie de contacto, lo que en teoría mejoraba la cicatrización y otorgaba a la técnica mayor versatilidad, pues permitía todo tipo de rotaciones a favor o en contra de los punteros del reloj y mayores retrocesos o avances mandibulares. Esto era muy importante en esos tiempos en que era justamente esta osteotomía la llamada a resolver todo tipo de problemas esqueletales, sin recurrir al maxilar (Figs. 1 y 2).

En Febrero 1977, Bruce Epker, ${ }^{3}$ publica tal vez la más significativa de las modificaciones de la técnica, haciéndola mucho más versátil, predecible y fácil. En ella ya no es necesario llegar hasta el borde posterior de la rama mandibular, sólo por encima y detrás de la espina de Spix; el borde inferior del cuerpo ha de ser abordando lo más perpendicular posi-

Prof. Asociado Cirugía Bucal y Máxilo Facial. Facultad de Odontología, Univ. de Chile. Santiago de Chile, Chile

\section{Correspondencia:}

Av. Kennedy 5735. Torre Poniente

Oficina 407. Las Condes

Santiago, Chile

\begin{abstract}
Bilateral Sagittal Split Osteotomy represents the most frequent surgical procedure being used in Orthognathic Surgery. Since Obwegeser first described has been modified in design, extension and instrumentation. With a revision of the most important modifications, this paper describe the technique being used by the author. Advantages, disadvantages and probable complications are also mentioned.
\end{abstract}

Key words: Sagital split osteotomy; Orthognathic surgery.

\section{Introduction}

Since Hugo Obwegeser described bilateral sagittal split ramus osteotomy (BSSROM) of the mandible in 1955, ${ }^{1}$ there have been many modifications of this surgical procedure, which undoubtedly is one of the surgical techniques most often used in orthognathic surgery. The most important contributions and modifications have been made by Gregorio Dal Pont, who in $1961^{2}$ suggested that the osteotomy be extended forward, then taken through the mandibular body to the height of the second and first molars, and from there, vertically downward to the basilar edge. This increased the contact surface, which theoretically improved and enhanced the versatility of the technique because it made possible all sorts of clockwise and counterclockwise rotations and forward and backward mandibular displacements. This was important at the time because this osteotomy was used to resolve many kinds of skeletal problems without resorting to maxillary surgery. (See Figures 1 and 2).

In February 1977, Bruce Epker ${ }^{3}$ published what may be the most significant modification of the technique, which made it much more versatile, predictable, and easy to perform. This modification eliminates the need to continue the cut to the posterior edge of the mandibular ramus, it is only necessary to bring it forward and up behind the Spix spine; the lower edge of the body must be approached as perpendicularly as possible and completely transected, to guide the surgical fracture through the lower alveolar canal. This can be done using osteotomes to split the ramus pro- 
ble y completamente transectado, para permitir guiar la fractura quirúrgica a través del conducto dentario inferior, lo que se puede hacer con el uso de osteótomos que abren la rama de forma progresiva y mucho menos traumática, pues en general evita la necesidad de usar el martillo y osteotomías con cinceles (Fig. 3).

Todo ello permite la visualización directa y cuidadosa del nervio dentario, hace predecible la fractura quirúrgica y acorta bastante los tiempos operatorios.

En mayo de 1977, el Dr W. H Bell, ${ }^{4}$ que en el concepto del autor es el padre de la Cirugía Ortognática moderna, nos entrega las «bases biológicas» de la osteotomía sagital en pro de modificaciones de la técnica que en efecto la hacían más amigable, menos engorrosa y con menos posibilidades de complicaciones. Su estudio determina las áreas de trabajo recomendadas en las nuevas técnicas para asegurar aporte sanguíneo y evitar posibles sufrimientos y complicaciones.

Con el advenimiento de la tecnología y la aparición de sierras reciprocantes con diseño ad hoc, Larry Wolford y cols., ${ }^{5}$ publican su modificación que intenta asegurar la separación de la mandíbula por el borde inferior de la misma y no por el conducto dentario, y lo hacen llevando la osteotomía por el dicho borde. Ello aseguraría una mayor superficie de contacto entre las partes y en especial, permitirían mayor superficie para la fijación de los segmentos.

Así, la evolución de la OSBRM ocurre en diseño, extensión e instrumentación. Estas modificaciones, en definitiva, la convierten en la técnica amigable, predecible, biológicamente aceptable y tremendamente versátil que es en la actualidad. Por cierto, que a partir de estas modificaciones centrales, ha habido múltiples otras que han aparecido y el autor ha podido constatar en varias ocasiones que cirujanos experimentados han adaptado la técnica a sus propios estilos. De hecho, a continuación se describe la que es su manera de realizar la técnica. Método acuñado durante varios años nos permite mayor cuidado del nervio mandibular, ya que con las técnicas relatadas anteriormente habitualmente es necesario manipular para desplazarlo de la zona de trabajo, lo que inevitablemente determina distintos grados de neuropraxia.

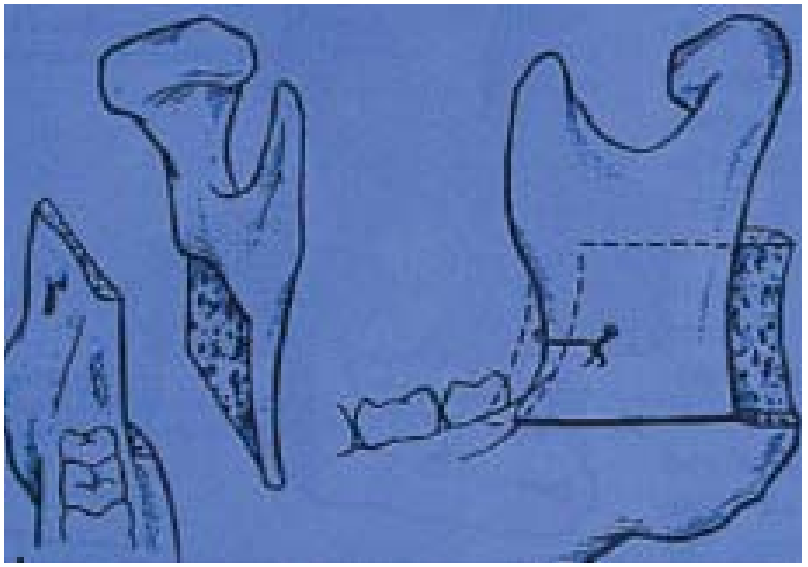

Figura 1. Esquema tomado del artículo original, que representa la Osteotomía Sagital original de Obwegesser.

Figure 1. Diagram from the original article showing Obwegesser's original sagittal split ramal osteotomy.

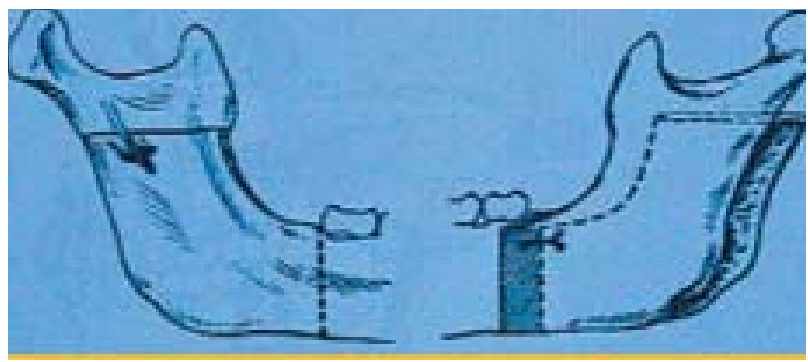

Figura 2. Esquema tomado del artículo original, que representa la modificación a la Osteotomía Sagital original propuesta por Giorgio Dal Pont.

Figure 2. Diagram from the original article showing the modification of the sagittal split ramal osteotomy proposed by Giorgio Dal Pont.

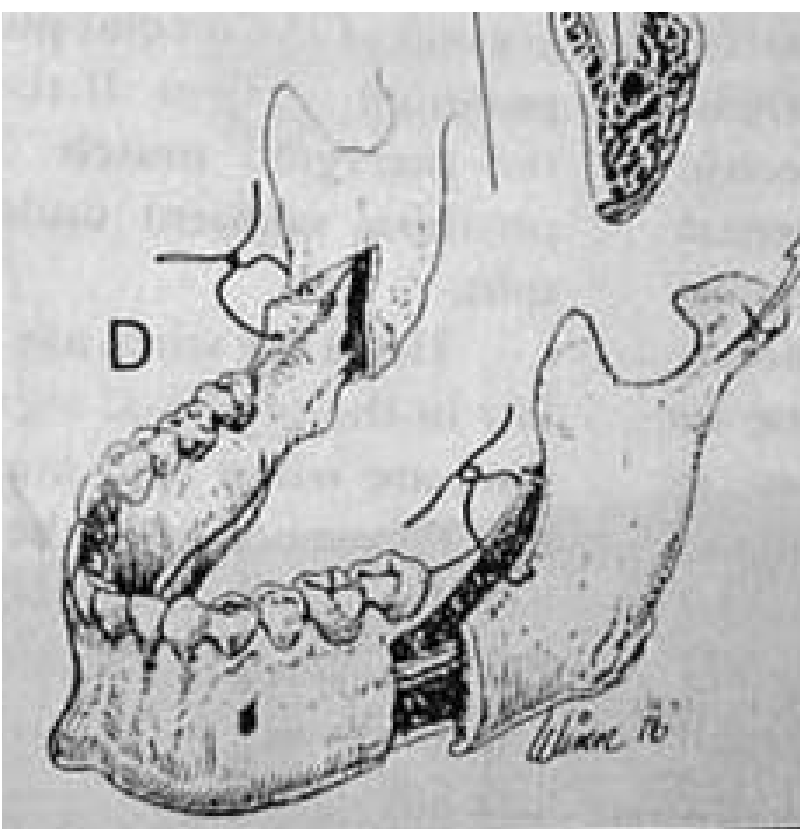

Figura 3. Esquema tomado del artículo original, que representa la modificación a la Osteotomía Sagital propuesta por Bruce Epker.

Figure 3. Diagram from the original article showing the modification of the sagittal split ramal osteotomy proposed by Bruce Epker gressively and much less traumatically because it generally eliminates the need to use hammer and chisels.

This allows the direct visualization and care of the dental nerve, increasing the predictability of the surgical fracture and shortening operating times.

In May 1977, Dr. WH Bell, ${ }^{4}$ who as the author of this article became the conceptual father of modern orthognathic surgery, established the biological bases of sagittal split ramal osteotomy. This enhanced the development of the technical modifications that in effect made it friendlier, less laborious, and less prone to complications. His study identified the recommended work areas for new techniques where the blood supply was ensured and potential suffering and complications could be prevented.

With technological advances and the appearance of the reciprocating surgical saw with an ad hoc design, Larry Wolford et al. ${ }^{5}$ published a modification that was designed to ensure that ramal splitting took place along the lower edge instead of the alveolar canal, extending the osteotomy along the edge itself. This increases the contact surface between parts and, in particular, provides a larger surface for segment fixation.

Thus, BSSROM evolved in design, extension, and instrumentation. These modifications definitely made it the friendly, predictable, biologically acceptable, and tremendously versatile technique that it now is. Arising from these key modifications, 


\section{Descripción de la técnica utilizada}

El abordaje sub perióstico del borde anterior de la rama y del trígono retro molar es el convencional. Luego, para restringir a lo estrictamente necesario el despegamiento de la cara interna de la rama mandibular, imaginariamente se trazan triángulos de referencia como los dibujados en las figuras. En número de tres, el primero puede estar representado por el área del tercer molar, si se encuentra erupcionado. El tercero corresponde a la apófisis coronoides y es en la unión de la base de este último con el vértice del segundo triángulo que se encuentra la espina de Spix y la sugerencia es ingresar a ese nivel sólo a despegar el túnel necesario para encontrar la espina, reparar en ella y alojar el separador que protegerá al paquete vásculo nervioso mandibular al momento de realizar el corte horizontal interno de la osteotomía (Figs. 4 a 7 ).

La osteotomía se realiza con hoja de sierra recíproca. Para el corte horizontal interno, se debe colocar la sierra alrededor de $5 \mathrm{~mm}$ por encima de la espina de Spix, de manera de poder penetrar con la sierra en $45^{\circ}$ hacia la medular y luego continuar directamente por el borde anterior de la rama. Este corte ha de ser completo desde el borde anterior hasta por detrás de la espina y de todo el espesor de la cortical interna. El corte se continúa en línea recta atravesando el trígono retromolar hacia fuera, donde igualmente recto se continua por la cara externa del cuerpo mandibular hacia el borde inferior, evitando dejar cortes angulares. La sierra ha de penetrar completa en profundidad, en la zona del trígono retro molar desde que se inicia el trazo vertical y en forma perpendicular. Al alcanzar la zona distal del último molar en boca, la sierra debe retirarse lo suficiente para no dañar el paquete vásculo nervioso mandibular y la angulación se va haciendo más tangencial al hueso en la medida de la progresión del corte a la pared lateral del cuerpo, donde ha de llegar aproximadamente a un impacto en $50^{\circ}$ al nivel del borde basilar.

Al llegar al borde basilar, de invierte la sierra para abordamiento desde abajo a arriba, manteniendo los $50^{\circ}$ de inclinación y asegurándose de cortar totalmente el borde, de manera de guiar la fractura quirúrgica que necesitamos para abrir la rama. Con esta forma de usar la sierra reciproca la mayor parte de las veces la apertura de la rama se produce más fácil y lateral al conducto, dejando el nervio dentro de su canal o al menos en el segmento distal, que es precisamente lo que
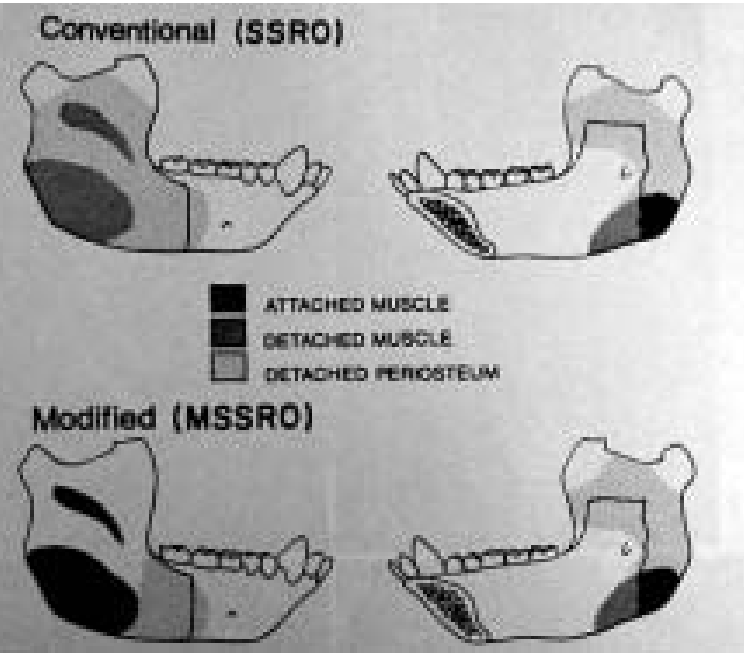

Figura 4. Esquema tomado del artículo original, que representa las .

Figure 4. Diagram from the original article showing the safe work areas recommended by William $\mathrm{H}$. Bell, which is where the modifications to the

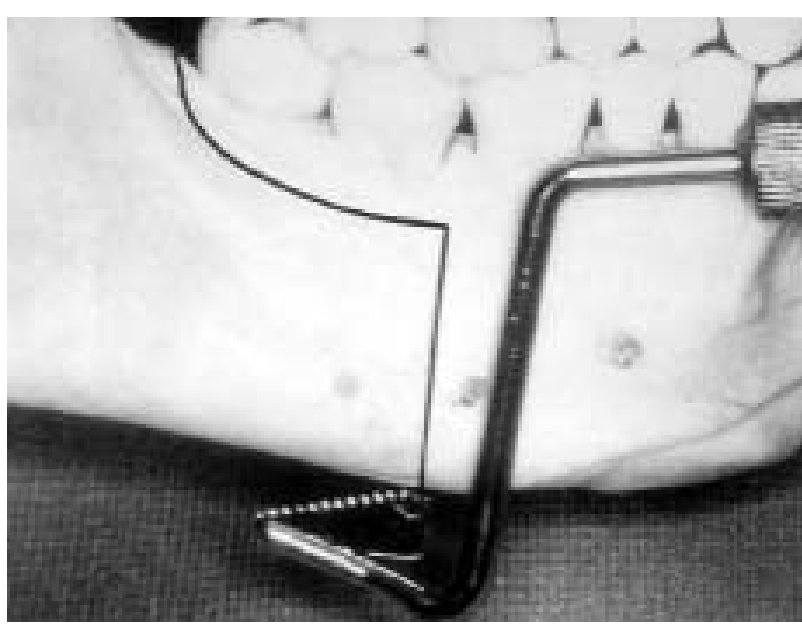

Figura 5. Esquema tomado del artículo original, que representa la

Figure 5. Diagram from the original article showing the modification of the sagittal split ramal osteotomy proposed by Larry Wolford and the use of a specially designed reciprocating saw. many others have appeared and the author has observed on several occasions that experienced surgeons adapt the technique to their own style. In fact, the author's own technique is described below. This method was developed over the course of several years and it protects the mandibular nerve more since the techniques previously described usually involve handling the mandibular nerve to separate it from the work area, which inevitably results in different degrees of neurapraxia.

\section{Description of the technique}

The subperiosteal approach to the anterior edge of the ramus and retromolar trigone is the usual approach. To restrict the spitting of the internal face of the mandibular ramus to what is strictly necessary, imaginary reference triangles like those shown in the figures are identified. There are three of these triangles, the first of which can be represented by the area of third molar, if it has erupted. The third triangle corresponds to the coronoid process and is located at the junction of the base of the coronoid process with the vertex of the second triangle, where the Spix spine is found. It is recommended that this area be entered only to open the tunnel necessary to find the spine, work in the area, and place the separator that will protect the mandibular vasculonervous package during internal horizontal osteotomy (see figures).

Osteotomy is performed with a reciprocating saw. For the medial horizontal cut, the saw should be placed about $5 \mathrm{~mm}$ above the Spix spine in order to enter with the saw at $a 45^{\circ}$ angle with respect to the medullary core and then continue directly along the anterior edge of the ramus. This cut must be complete from the anterior edge to just behind the spine and through the entire thickness of the medial cor- 
evita tener que manipularlo. Una vez abierta las ramas, es importante recordar la necesidad de despegar la inserción del músculo pterigoideo en la cara interna de la rama, como lo sugiere Epker, y asegurarse de evitar causas de daño neurológico al reponer los fragmentos entre sí (Figs. 8 a 13).

La fijación interna rígida ha sido un aporte extraordinario para la OSBRM. Aún cuando durante los primeros años hubo muchos que preconizaron evitar la utilización de placas y/o tornillos para fijar los segmentos, pues en su opinión ello implicaba problemas articulares témporo mandibulares, cada vez más la literatura y autores de la técnica abandonan el uso de alambres a favor de fijación interna rígida. Sea con la utilización de placas y tornillos mono corticales o el uso de tornillos bicorticales, pues ambas técnicas proveen una inmovilización adecuada de los segmentos (fijación rígida), especialmente para los efectos de la posición del cóndilo mandibular en la fosa articular; la técnica debe cumplir con importantes requisitos para evitar alteraciones en la articulación témporo mandibular.

\section{Indicaciones}

En la actualidad, con certeza podemos decir que la Osteotomía Sagital Bilateral de Rama Mandibular está indicada cada vez que se requiera alguna movilización esqueletal mandibular al nivel de la rama mandibular. Esto se traduce en que la OSBRM es útil en casos de avances y retrocesos mandibulares, a los cuales se puede imprimir cualquier tipo y grado de rotación, tanto a favor como en sentido contrario a las agujas del reloj. También esta indicada para movimientos verticales posteriores, tanto cuando se requiere seguir el movimiento de intrusión posterior del maxilar, en un caso de cirugía bimaxilar, como cuando el movimiento es el opuesto, aunque ello es bastante menos frecuente por razones biomecánicas. En el sentido transversal, por cierto que es la técnica de elección para casos de asimetría mandibular, en los que se requiere desplazar el arco mandibular hacia delante en un lado y hacia atrás en el otro.

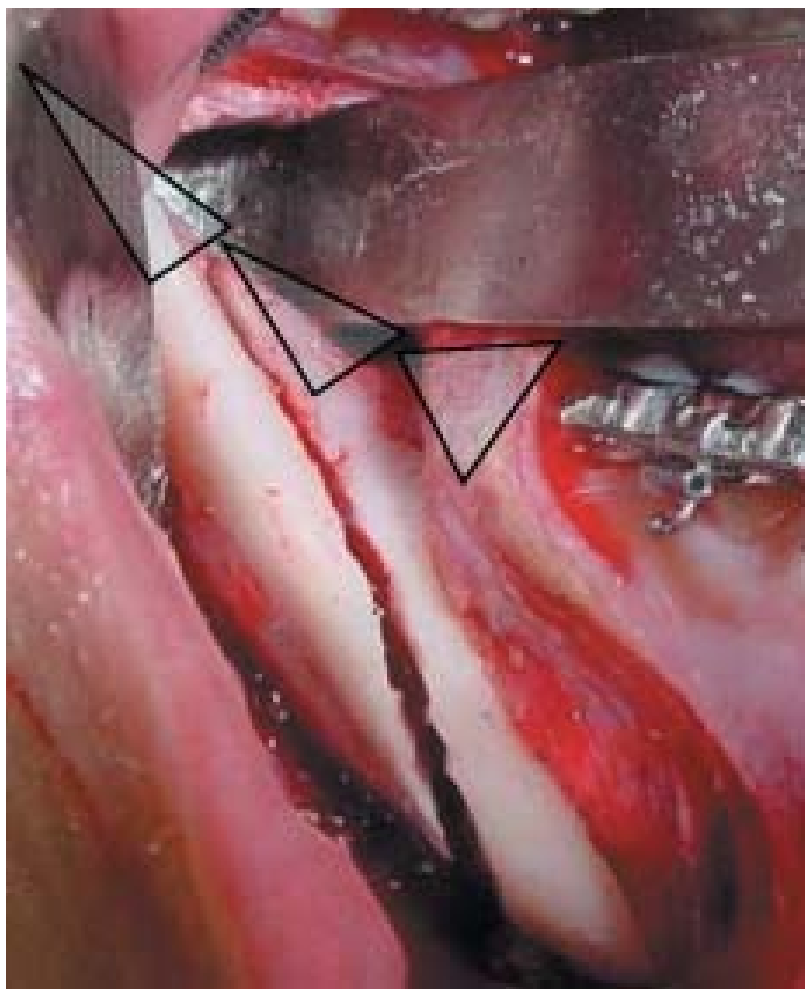

Figura 6. Fotografía con la Visualización de los triángulos para ubicar la espina de Spix.

Figure 6. Photograph showing the triangles to locate the Spix spine.

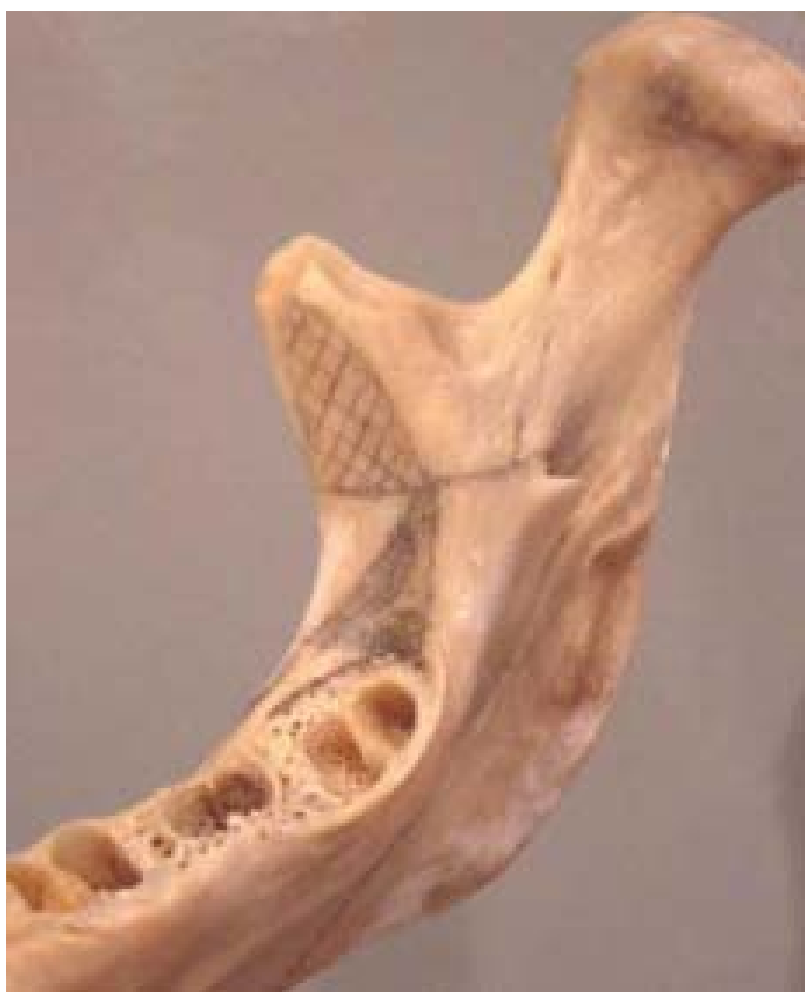

Figura 7. En mandíbula seca se aprecia que la espina se encuentra a la altura de la unión de los dos triángulos superiores.

Figure 7. In a clean jaw it is observed that the spine is at the height of the junction of the two upper triangles. tex. The cut continues in a straight line that crosses the retromolar trigone and then goes outwards, continuing with an equally straight line along the external face of the mandibular body towards the lower rim, avoiding angular cuts. The full depth of the saw should enter the retromolar trigone zone from the beginning of the vertical line and perpendicularly. When the cut reaches the distal part of the last molar in the mouth, the saw should be withdrawn enough to avoid damaging the vasculonervous mandibular package. The angle should be more tangential to the bone as the cut progresses to the lateral wall of the mandibular body, where it should form an angle of approximately $50^{\circ}$ with the basilar edge.

When the saw reaches the basilar edge, it is inverted to cut the mandible upward, maintaining a $50^{\circ}$ slant and making sure that the edge is completely cut, thus guiding the surgical fracture needed to split the ramus. Using the reciprocal saw in this way, the ramus can generally be split more easily and lateral to the alveolar canal, leaving the nerve, or at least its distal segment, in the canal, where we can avoid manipulating it. Once the rami are split, it is important to remember to separate the insertion of the pterygoid muscle from the medial face of the ramus, as Epker suggests, and to take care to avoid causes of neurological damage when realigning the fragments.

Rigid internal fixation has been an extraordinary 

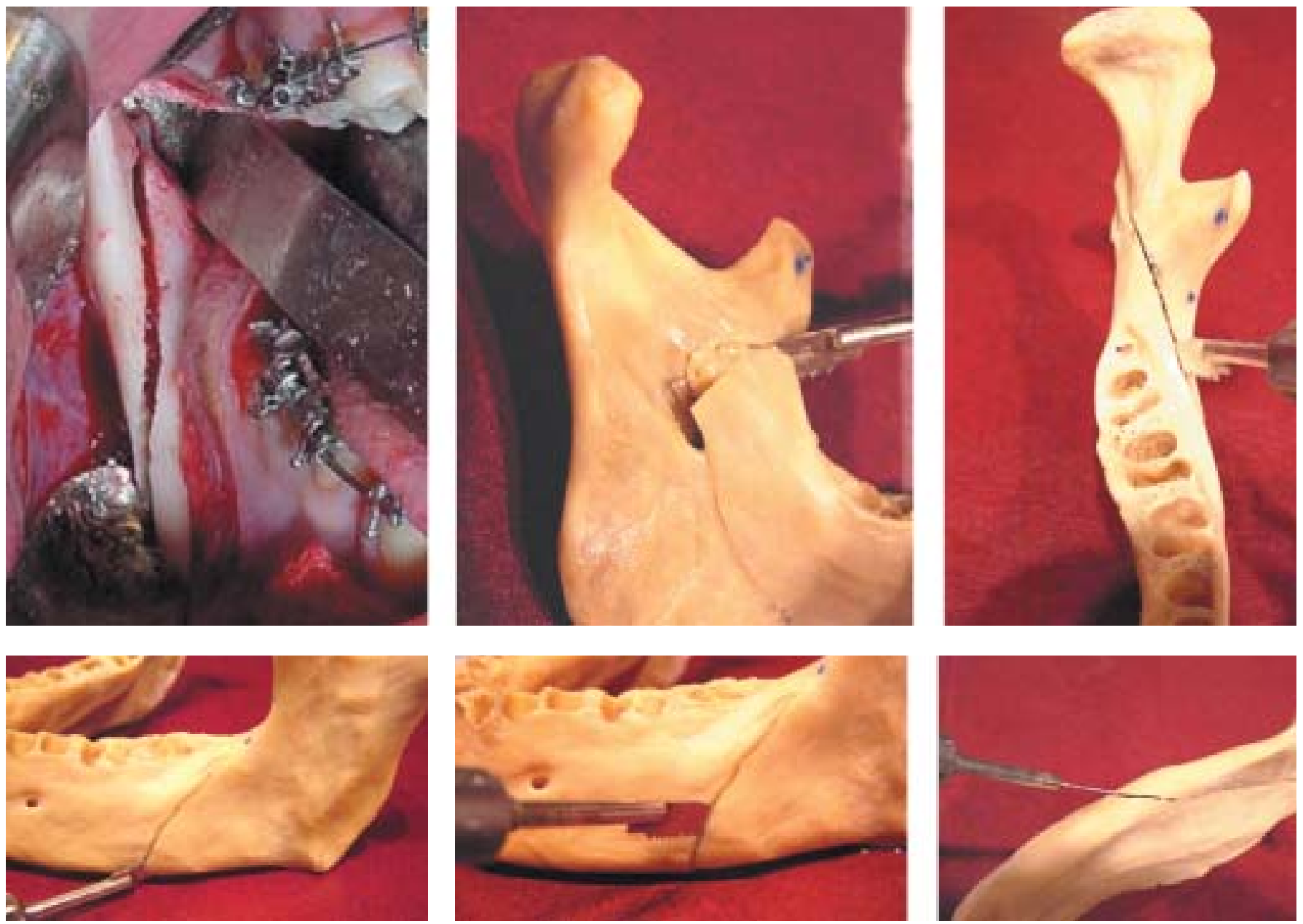

Figuras de 8 a 13. Esta secuencia de figuras muestra la técnica relatada en el texto. Relación con espina de Spix y ángulo de ataque (8). Diseño recto vertical por el borde inferior $\left(9\right.$ y 10 ). Corte sin ángulos rectos a nivel de cuerpo y en el borde inferior con una angulación de aproximadamente $50^{\circ}$ y con transacción completa del borde inferior $(11,12$ y 13$)$.

Figures 8-13. This sequence of figures shows the technique described in the text. Relation with Spix spine and angle of approach (8). Vertical straight design along the lower rim (9 and 10). Cut with no right angles in the body and lower edge at an angle of approximately $50^{\circ}$ and complete transection of the lower rim $(11,12$, and 13$)$.

Cada vez que aplicamos una técnica quirúrgica en diferentes casos y situaciones, tenemos que adaptarla a los requerimientos del caso. Ello es especialmente importante en el caso de utilizar la OSBRM en movimientos asimétricos de la mandíbula, en los que el grado de divergencia de las ramas mandibulares puede hacer que se produzcan rotaciones indeseables de los segmentos proximales, pudiendo ocasionar inadecuadas resultados estéticos por asimetrías a nivel de cuerpo mandibular, o lo que es peor, provocar alteraciones funcionales de la articulación témporo mandibular.

\section{Ventajas de la OSBRM}

Entre las múltiples ventajas de la OSBRM, realizada según lo mencionado, las más notables son 1) La gran versatilidad de sus indicaciones, 2) La posibilidad de utilizar fijación interna rígida para unir los fragmentos osteotomizados, con las innumerables ventajas que ello significa y 3) La ausencia de complicaciones quirúrgicas derivadas de viabilidad de los segmentos, estabilidad de los segmentos o cicatrización ósea. advance in BSSROM. Even though many authors recommended avoiding the use of plates and/or screws to fix the segments in the early years, because it was thought that this would originate problems in the temporomandibular joints, reports in the literature and by specialists in the technique indicate that they are abandoning the use of wires in favor of rigid medial fixation with an increasing frequency. Whether plates and monocortical screws or bicortical screws are used, since both techniques adequately immobilize the segments (rigid fixation), particularly when securing the position of the mandibular condyle in the articular glenoid fossa, the technique must satisfy certain important requirements to prevent problems in the temporomandibular joint.

\section{Indications}

At present, we can certainly say that bilateral sagittal split ramal osteotomy of the mandible is indicated whenever skeletal mobilization of the mandibular ramus is required. 


\section{Desventajas de la OSBRM}

Estas se refieren principalmente al grado de exigencia de la técnica y que no implica dificultad técnica para realizar los cortes óseos o separar las ramas, sino específicamente en el respeto de la posición condilar de cada uno de los segmentos proximales mandibulares. La experiencia del cirujano es la mejor manera de evitar complicaciones al respecto pero, por otro lado, no podemos aceptar que dicha experiencia deba venir por el proceso de ensayo y error. Es por eso que debemos insistir en que, antes de realizar una OSBRM como la descrita en este artículo, con fijación interna rígida, el cirujano debe tener suficiente entrenamiento en el uso de placas y tornillos. Además, es altamente deseable que tenga manejo de planificación ortodóncica quirúrgica, lo que implica el uso de articuladores semi ajustables y manejo de técnicas de desprogramación neuro muscular y toma de registros en relación céntrica. Esto últimos para poder planificar, realizar cirugía de modelos y confeccionar sus splints o férulas quirúrgicas en relación céntrica mandibular, que es el punto de partida de toda planificación y la mejor manera de tratar a las articulaciones témporo mandibulares.

El método o técnica de fijación rígida propiamente dicha en sus detalles, escapa al objetivo de este artículo y de seguro será motivo de alguna publicación ulterior.

\section{Posibles complicaciones}

Las complicaciones de la OSBRM pueden ser divididas en aquellas de tipo intra operatorias y post operatorias. Son complicaciones intra operatorias atribuibles a la técnica las siguientes:

- Fracturas indeseables. En cualquiera de las modificaciones de la técnica, incluyendo la forma utilizada por el autor, es posible tener una fractura de la cara externa de la rama en el segmento proximal, la que habitualmente es de tipo parcial y deja un fragmento de variable tamaño sin fijación a ningún pedículo de tejido blando o duro. Si la fractura es alta y lateral al conducto dentario, es posible que el segmento proximal siga unido al arco dentario y que el cirujano no advierta que al llevar los dientes a oclusión estará sacando completamente de la fosa articular al cóndilo mandibular, determinando la casi obligación de una re operación inmediata. Es siempre recomendable verificar las características de los segmentos proximales y distales y la disociación que debe existir entre ambos, logrando libre movilización de uno con respecto al otro.

- Daño a las estructuras vásculo nerviosas. También atribuible a la técnica y tiene relación tanto con la abertura de las rama como con la fijación interna rígida. En lo que se relaciona con las osteotomías y abertura de la rama, esta es una complicación que con las modificaciones relatadas es cada vez menos frecuente. Sin embargo, en ningún caso se puede decir que se puede evitar neuropraxia del nervio dentario inferior, que es lo que provoca las alteraciones de la sensibilidad de labios inferiores y mentón que todos conocemos y que se relacionan con la OSBRM. En una evaluación realizada por el autor sobre 400 casos operados, los resultados son fueron: $70 \%$ de los pacientes presentaron alguna alteración neurosensorial. De ese $70 \%$, el $20 \%$ es anestesia a los 10 días post operatorios. El resto son porcentajes variables de hipoestesia o hiperestesia. El 50\% de
This means that BSSROM is useful in cases requiring forward or backward repositioning of the mandible, to which any type or degree of rotation, whether clockwise or counterclockwise, can be added. It is also indicated for posterior vertical repositioning, as a complement to posterior intrusion of the maxillary in the case of bimaxillary surgery, or for the opposite movement, although this is less common due to biomechanical reasons. In a cross-sectional direction, it is the technique of choice for cases of mandibular asymmetry, in which the mandibular arc has to be moved forward on one side and backward on the other side.

Whenever a surgical technique is applied in different cases and situations, it must be adapted to the requirements of the case. This is especially important in cases in which $B S S R O M$ is used in asymmetrical jaw repositioning, in which the degree of divergence of the mandibular rami can cause unwanted rotation of the proximal segments, which may produce undesirable aesthetic results due to the asymmetry of the mandibular body or, what is worse, functional alterations of the temporomandibular joint.

\section{Advantages of BSSROM}

Among the many advantages of BSSROM when performed as described, the most noteworthy are 1) the versatility of its indications, 2) the possibility of using rigid internal fixation to join osteotomized fragments, which has innumerable advantages, and 3) the absence of surgical complications related to segment viability, segment stability, or bone healing.

\section{Disadvantages of BSSROM}

The disadvantages of the technique refer mainly to the demands of the technique. While it is not technically difficult to perform the bone cuts or separate the rami, ensuring the proper condylar position of each of the proximal mandibular segments requires special attention. The experience of the surgeon is the best guarantee against complications but it is unacceptable to gain experience by a process of trial and error. This is why we must insist that surgeons have sufficient training in the use of plates and screws before performing a BSSROM like the one described in this article, with rigid internal fixation. In addition, it is highly desirable that the surgeon be capable of managing surgical orthodontic planning, which involves the use of semi-adjustable articulators, techniques of neuromuscular deprogramming, and taking impressions in a relation to a central point. These skills are needed for planning, performing model surgery, and preparing surgical splints in relation to the mandibular center, which is the starting point of all planning and the best way to handle temporomandibular joints.

The details of the rigid fixation method or technique per se are beyond the scope of this article and surely will be the topic of a future publication. 
los pacientes que hacen trastornos de la sensibilidad, se revierte completamente a los 3 meses. La mitad que persiste con alteraciones, se recupera paulatinamente llegando casi a un $5 \%$ de ellos (19 pacientes) que tiene trastornos por más de 6 meses; 8 pacientes, representando el $2 \%$ de los pacientes evaluados persisten con hipoestesia funcional por más de un año. Para el autor hipoestesia funcional es aquella en que existiendo menor grado de respuesta a los test realizados (tacto, discriminación direccional y de dos puntos y dolor), no implica para el paciente ningún problema en su vida diaria. Esta evaluación fue realizada antes de poner en práctica rutinaria la técnica descrita en este artículo y, si bien podemos ver mejores resultados, no se ha realizado una evaluación adecuada para tener evidencias suficientes.

Son complicaciones post operatorias atribuibles a la técnica las siguientes:

- Mala Oclusión post operatoria inmediata. Toda oclusión diferente a la planificada en la cirugía de modelos, ha de considerarse una complicación. Esta mala oclusión puede o no acompañarse o ser incluso debida a una mala posición del cóndilo en la fosa mandibular. Si la razón de la mala oclusión es una distracción condilar, que es lo más probable, la sugerencia del autor es reintervenir al paciente para recolocar los segmentos proximales como corresponda. De otra manera, se está poniendo en riesgo la estabilidad funcional de todo el tratamiento a medio y corto plazo. Si la alteraciones oclusales coexisten con una adecuada posición condilar, se recomienda al Ortodoncista evaluar la posibilidad de realizar las movilizaciones dentarias que corresponda con el fin de lograr el objetivo oclusal funcional, que no es sino una oclusión orgánica mudamente protegida. Si ello es posible, es el camino a seguir, aún cuando ello implica alargar el tiempo de tratamiento ortodóncico post operatorio.

- Mala Oclusión tardía. En este caso debemos pensar en un problema de estabilidad esqueletal. La estabilidad en Cirugía Ortognática, más que al tipo de fijaciones utilizadas, está relacionada con la integridad estructural y funcional de las articulaciones témporo mandibulares y también a la oclusión final del caso y su funcionalidad. La inestabilidad oclusal, con características inorgánicas, con contactos deflectivos o prematuros, sin guías caninas y anteriores, son el principal factor de estabilidad ortodóncica y por ende esqueletal en los pacientes que han sido sometidos a cirugía ortognática. Ahora, dicha inestabilidad no es atribuible a la OSBRM. Por otro lado, la integridad estructural de las ATM's se refiere específicamente a la reabsorción condilar progresiva, necrosis avascular o lisis condilar, como se le quiera llamar. Esta suelen presentarse en pacientes que han sido sometidas a OSBRM como técnica única o combinada y ocurriría en mujeres jóvenes que tienen un componente bioquímico (hormonal) y un componente biomecánico predisponerte. En el caso de presentarse, la reabsorción condilar lleva a una pérdida de dimensión vertical esqueletal que se traduce en una mordida abierta anterior, que será proporcional al grado de reabsorción condilar. En el caso de una reabsorción unilateral, lo que no es frecuente, se podría esperar un componente asimétrico hacia el lado afecto. Nada ha sido publicado que establezca una relación causa efecto entre OSBRM y la aparición de reabsorción condilar.

\section{Possible complications}

The complications of BSSROM can be divided into intraoperative and postoperative complications. The intraoperative complications are attributable to the technique:

- Unwanted fractures. In any of the modifications of the technique, including the form used by the author, a fracture of the proximal segment of the external face of the ramus can occur. Such fractures are usually partial and leave a fragment of variable size with no connection to any soft or hard tissue pedicle. If the fracture is high and lateral to the alveolar canal, the proximal segment may remain joined to the dental arc and the surgeon will not notice that the mandibular condyle has slipped out of the glenoid fossa when placing the teeth in occlusion. This complication will almost certainly require immediate re-operation. It is always advisable to check the proximal and distal segments and the dissociation that should exist between them; segments should move freely with respect to each other.

- Damage to vasculonervous structures. This complication is also attributable to the technique and related to both ramal splitting and rigid internal fixation. With regard to the osteotomies and ramal splitting, this complication is becoming increasingly less frequent due to the modifications described. Nevertheless, in no case can it be claimed that neurapraxia of the inferior dental nerve can be avoided, which is what causes the disturbances in the sensitivity of the lower lip and chin that are known to everyone and are related to BSSROM. In an evaluation made by the author of 400 operated cases, the results were: neurosensorial disturbances in $70 \%$ of the patients. Of this 70\%, 20\% suffered anesthesia 10 days after surgery. The rest were variable percentages of hypoesthesia or hyperesthesia. In 50\% of the patients who suffered sensitivity disturbances, these remitted completely within 3 months. The other half of the patients with persistent disturbances recovered gradually. Almost 5\% (19 patients) had disturbances that persisted for more than 6 months. Eight (8) patients, representing $2 \%$ of the patients evaluated, had functional hypoesthesia lasting more than a year. For the author, functional hypoesthesia produces a reduced response to testing (touch, directional and two-point discrimination, and pain), but does not create any problem for the patient's daily life. This evaluation was made before the technique described in this article was put into routine practice. Although we have seen better results, no adequate evaluation has been made to obtain firm evidence.

The following postoperative complications are attributable to the technique:

- Immediate postoperative malocclusion. Any occlusion different from that planned in the surgery of models must be considered a complication. This malocclusion may or 
Sin embargo, no podemos dejar de considerarlo, pues aparece en pacientes que han tenido Cirugía ortognática y específicamente la osteotomía que nos preocupa.

\section{Bibliografía}

1. Trauner R, Obwegeser H. Zur Operationstechnik Bei der Progenie und anderen Unterkieferanomalien. Dtsch Zahn-Mund-Kieferheilk 23 (1955-56) 1.

2. Dal Pont Giorgio. J Oral Surg. Anesth \& Hosp.D. Serv Vol. 19. En. 1961.

3. Epker N. Bruce. Modifications in the sagittal osteotomy of the mandible. J Oral Surgery 1977 Vol. 35.

4. Bell H. William. Biological basis for modification of the sagittal ramus split operation. J Oral Surgery Mayo 1977 Vol. 35.

5. Wolford L. The Mandibular Inferior Border Split. J Oral Surgery 1990;48:92-4.

6. Quevedo L, Ruiz J, Figueroa L. Técnica Quirúrgica de Cirugía Ortognática para Ortodoncistas. Parte II. Rev Chil Ortodoncia 1989;6:31-5.

7. Quevedo L, y cols. Estética Facial para el Cirujano Máxilo Facial. Rev Dental de Chile 1991;82:36-40. may not be accompanied by malposition of the condyle in the mandibular glenoid fossa, or may even be due to it. If the cause of the malocclusion is condylar distraction, which is the most likely, the author recommends re-operation to reposition the proximal segments, as necessary. Otherwise, the functional stability of any short-term or intermediate-term treatment would be at risk. If occlusal disturbances coexist with an adequate condylar position, it is recommended that the orthodontist evaluate the possibility of performing dental mobilizations to achieve objective functional occlusion, which is no more than a mutely protected organic occlusion. If feasible, this is the route to take, even though it involves prolonging postoperative orthodontic treatment time.

- Delayed malocclusion. In this case we should think about the presence of a problem of skeletal stability. Stability in orthognathic surgery is related, more than to the type of fixations used, to the structural and functional integrity of the temporomandibular joints and to the final occlusion and its functionality. Occlusal instability, which is of inorganic characteristics and produces deflective or premature contacts without canine and anterior guides, is the main factor in orthodontic and, ultimately, skeletal stability in patients who have undergone orthognathic surgery. This instability is not attributable to BSSROM. On the other hand, the structural integrity of the temporomandibular joint is specifically related to progressive condylar resorption, avascular necrosis, condylar lysis, or the preferred designation. This complication usually appears in patients who have undergone BSSROM as a single or combined technique and in young women who have a predisposing biochemical (hormonal) and biomechanical component. If it occurs, condylar resorption causes a loss of skeletal height, which translates into an anteriorly open bite that is proportional to the degree of condylar resorption. In the case of unilateral resorption, which is infrequent, an asymmetrical component toward the affected side can be expected. Nothing has been published that establishes a cause-effect relation between BSSROM and the appearance of condylar resorption. Nevertheless, we cannot ignore it because it appears in patients who have undergone orthognathic surgery and, specifically, the osteotomy that concerns us. 